\title{
Estimated Fuel Burn Performance for MDW Arrivals
}

\author{
Akshay Belle* and Lance Sherry ${ }^{\dagger}$ \\ Center for Air Transportation Systems Research, Fairfax, Virginia, 22030
}

\begin{abstract}
The Terminal Radar Approach Control (TRACON) arrival flows are an important component of overall NAS efficiency and airline costs of operation. The efficiency of TRACON arrival flows is a function of the relative position of the final waypoint on the Standard Terminal Arrival Route (STAR) to the runway threshold, the type of approach (ILS, RNP, VFR), and the arrival vertical and longitudinal profile. A previous research established the presence of 16 unique arrival flows for the main runways $(31 \mathrm{C}, 4 \mathrm{R}, 22 \mathrm{~L}$ and 13C) at Midway International Airport (MDW), using 43 days of National Offload Program (NOP) radar track data. This paper uses an aerodynamic fuel burn model to estimate the fuel burn for these flows.

The results of the analysis indicate that, during Instrument Meteorological Conditions (IMC), the RNP approach to $13 \mathrm{C}$ uses an average of $14 \%$ less fuel than the ILS approach on to $13 \mathrm{C}$. For narrow body aircrafts, this is equivalent to on an average a savings of $\$ 47$ per flight per approach (at $\$ 3$ a gallon). During Visual Meteorological Conditions (VMC) the least average fuel burn arrival flow for VFR approach procedures is to runways $4 R$ or 31C $(174.9 \mathrm{~kg})$ followed by $13 \mathrm{C}(+11 \%)$, and 22L $(+19 \%)$. During Instrument Meteorological Conditions (IMC) the least average fuel burn arrival flow for ILS approach procedures is to runway $31 \mathrm{C}(207.06 \mathrm{~kg})$ followed by, $4 \mathrm{R}(+6.5 \%)$ and $13 \mathrm{C}(+33 \%)$. To ensure equity in fuel burn between flights arriving from the east and the west during VMC, 13C is the most equitable runway with the $14 \%$ difference in fuel burn between east and west flows, followed by $4 \mathrm{R}$ (18\% difference), 22L (96\% difference) and 31C (148\% difference). During IMC, $13 \mathrm{C}(56 \%)$ is the most equitable runway followed by $4 \mathrm{R}(72 \%)$ and $31 \mathrm{C}(211 \%)$.

For narrow body aircrafts at MDW, the fuel burn rate in level flight $(35 \mathrm{~kg} / \mathrm{min})$ is $108 \%$ greater than the fuel burn for near-idle descent segments $(15 \mathrm{~kg} / \mathrm{min})$ and $25 \%$ greater than fuel burn on the final approach segment $(25 \mathrm{~kg} / \mathrm{min})$. These results quantify the benefits of the RNP approach onto 13C and identify an opportunity for a decision-support tool to select runway configuration based on wind magnitude/direction, as well as fuel burn.
\end{abstract}

\section{Introduction}

$\mathrm{T}$ he Terminal Radar Approach Control (TRACON) arrival flows are an important components of the efficiency of the National Airspace System (NAS) as well as the efficiency of airline operations. The efficiency of TRACON arrival flows is a function of the relative position of the final waypoint on the Standard Terminal Arrival Route (STAR) to the runway threshold, the type of approach (ILS, RNP, VFR), and the arrival vertical and longitudinal profile.

A previous research established the presence of 16 unique arrival flows for the main runways $(31 \mathrm{C}, 4 \mathrm{R}, 22 \mathrm{~L}$ and 13C) at Midway International Airport (MDW), using 43 days of National Offload Program (NOP) radar track data ${ }^{1}$.

The objective of this research is to estimate fuel burn performance for arrival flows (i.e. from the final waypoint in the Standard Terminal Arrival Route (STAR) to the runway threshold via a type of approach) at Chicago Midway International Airport (MDW) using actual trajectory of the aircraft, while taking into consideration the energy state (kinetic - true air speed and potential - altitude) of the aircraft at each position report of the flight trajectory. The equations for thrust, drag, fuel burn, and the various aircraft related coefficients are obtained from the Base of Aircraft Data (BADA v3.8) $)^{2}$. The wind information required to estimate the true airspeed at various altitude is estimated by applying the power law wind profile equation ${ }^{3}$ to the Aviation System Performance Metrics (ASPM)

\footnotetext{
${ }^{*}$ Ph.D. Candidate, George Mason University, 4400 University Dr, MS:4A6, Fairfax, VA.

${ }^{\dagger}$ Associate Professor, George Mason University, 4400 University Dr, MS:4A6, Fairfax, VA.
}

1

American Institute of Aeronautics and Astronautics 
surface wind information. The true airspeed is computed using the ground speed derived from the NOP track data and the estimated wind information ${ }^{4}$.

The analysis is conducted using C90 TRACON's National Offload Program (NOP) data for 43 days selected to provide data for the 16 flows. The fuel burn is computed for 98 aircraft types (jets and turbo props) at MDW. The narrow body aircrafts account of $76 \%$ of the flights, followed by business jets (15\%), regional jets (5\%) and turbo props $(4 \%)$. The most dominant aircraft type, the Boeing 737 's, accounts for $72 \%$ of the flights at MDW.

The results of analysis are summarized as follows:

(1) During Instrument Meteorological Conditions (IMC), the RNP approach to 13C requires an average of 14\% less fuel than the ILS approach on to 13C. For narrow body aircrafts, this is equivalent to on an average a savings of $\$ 47$ per flight per approach (at $\$ 3$ a gallon).

(2) During Visual Meteorological Conditions (VMC), assuming existing mix of arrivals from the east and west, the least average fuel burn arrival flow for VFR approach procedures is to runways $4 \mathrm{R}$ and $31 \mathrm{C}(174.9 \mathrm{~kg})$ followed by $13 \mathrm{C}(+11 \%)$, and $22 \mathrm{~L}(+19 \%)$.

(3) During Instrument Meteorological Conditions (IMC), assuming existing mix of arrivals from the east and west, the least average fuel burn arrival flow for ILS approach procedures is to runways $31 \mathrm{C}(207.06 \mathrm{~kg})$ followed by $4 \mathrm{R}(+6.5 \%)$ and $13 \mathrm{C}(+33 \%)$.

(4) $13 \mathrm{C}$ is the most equitable runway with the $14 \%$ difference in fuel burn for VFR flights from the east and the west followed by, 4R (18\%), 22L (96\%) and 31C (148\%). The same is true during IMC, 13C (56\%) is the most equitable runway followed by $4 \mathrm{R}(72 \%)$ and $31 \mathrm{C}(211 \%)$.

(5) For narrow body aircraft at MDW, the fuel burn rate in level flights (35 kg/min) is $108 \%$ greater than fuel burn for near-idle descent segments $(15 \mathrm{~kg} / \mathrm{min})$ and $25 \%$ greater than fuel burn on the final approach segment $(25 \mathrm{~kg} / \mathrm{min})$

This paper is organized as follows: the next section provides an overview of MDW and the C90 arrival flows. The following section describes the methodology for estimating fuel burn using track data, followed by a section describing the results of fuel burn performance analysis for MDW arrivals, and finally the Conclusions section describes the implications of these results and future work.

\section{Overview of MDW and TRACON Arrival Flows}

MDW has four major runways, 13C, 31C, 4R, and 22L (Figure 1). Runways 13C, 31C and 4R have ILS approaches. Runway $13 \mathrm{C}$ has an RNP approach as well. For arrivals into MDW, there are three STARs one from the west and two from the east ${ }^{\ddagger}$. The two STARs (one RNAV and one conventional) from the east terminate at Chicago Heights VORTAC (CGT), and the STAR from the west terminates at Joliet VORTAC (JOT). These final waypoints on the STAR (shown in Figure 2) feed traffic into the terminal area at MDW.

\footnotetext{
${ }^{\ddagger}$ On June $27^{\text {th }} 2013$, three new STARs and four new approach types were published. This analysis was done prior to these changes.
} 


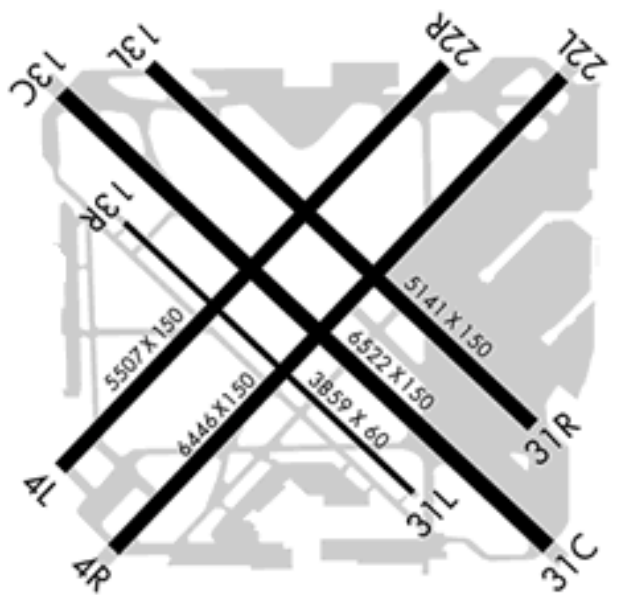

Figure 1. MDW runway Configuration (Source: airnav.com)

The location of the final waypoint on the STAR with respect to the runways determines the direction from which the traffic flows. These combined with the runway and arrival approach procedure characterize various TRACON flows. The flows originate at one of two final way point on the STAR (east - Chicago Heights, or west - Joliet), and then follow a prescribed trajectory according to the type of approach (ILS, RNP, or VFR) to each runway. Based on this characterization process a total of 28 flows are possible at MDW.

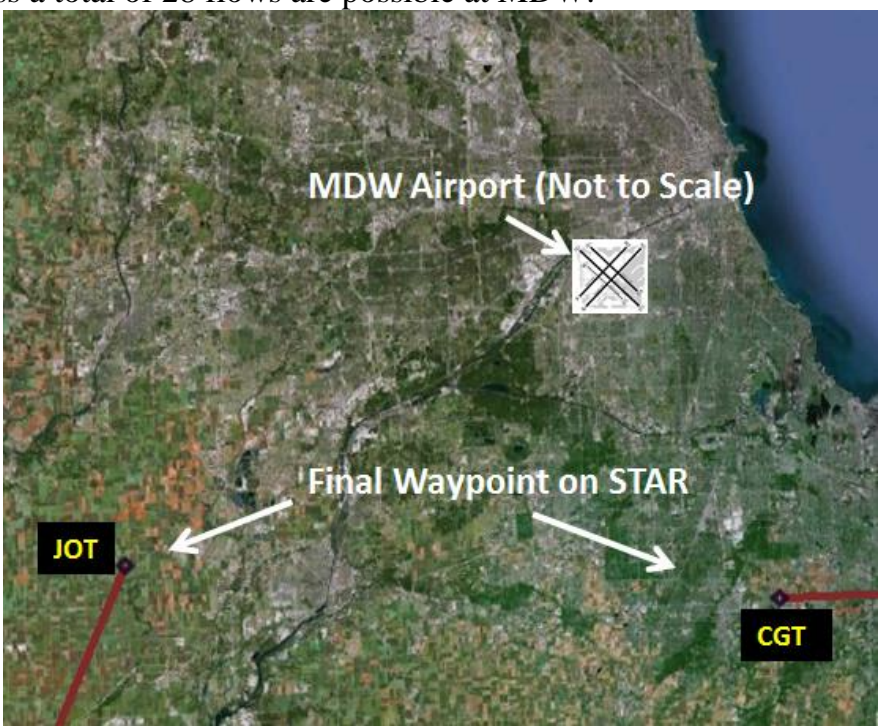

Figure 2. Location of the Final Waypoint on the STAR w.r.t the Airport (MDW)

A previous analysis of arrival flows at MDW, using National Offload Program (NOP) track data identified 16 flows (used by $98 \%$ of the flights) on to the major runways $13 \mathrm{C}, 31 \mathrm{C}, 22 \mathrm{~L}$ and $4 \mathrm{R}$ at $\mathrm{MDW}^{1}$. The remaining six runways (and the corresponding 12 flows) were seldom used. The fuel burn estimates in this analysis are limited to these 16 flows. A sample of these flows is shown in Figure 3 and Figure 4. The major flows from the east and the west are, the ILS, RNP and Visual approaches on to runway 13C, the ILS and Visual approaches on to runway $4 \mathrm{R}$ and $31 \mathrm{C}$ and the Visual approaches on to runway $22 \mathrm{~L}$. 


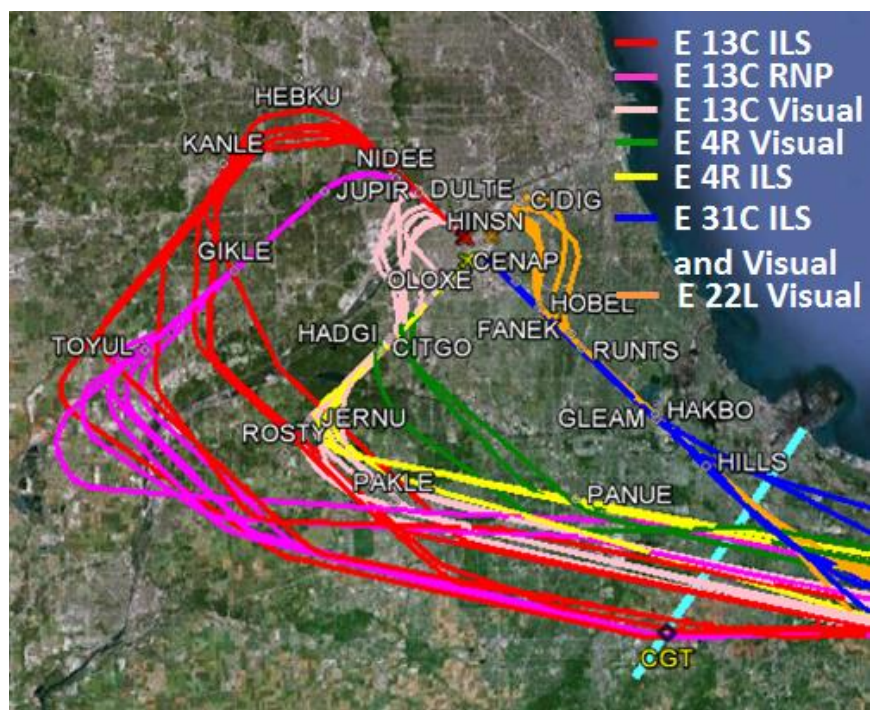

Figure 3. Sample TRACON flows at MDW from the east

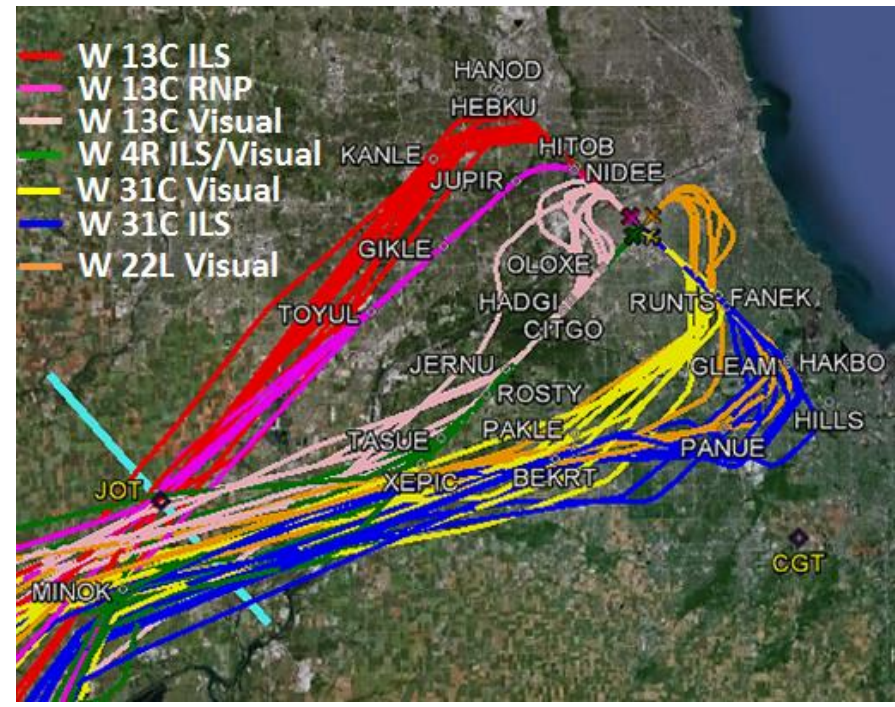

Figure 4. Sample TRACON flows at MDW from the west

\section{Methodology}

\section{A. Data Used}

This analysis uses data from three sources, the National Offload Program (NOP) ${ }^{5}$ data, the Aviation System Performance Metrics (ASPM) ${ }^{6}$ airport data and the Base of Aircraft Data (BADA v 3.8) ${ }^{2}$.

The NOP service operated by the FAA collects NAS operational data including flight tracks for Terminal Radar Approach Control Facilities (TRACONs). Flight tracks contain identifying flight number, aircraft type and the four dimension (4D) position report consisting of the latitude, longitude, altitude, and timestamp. The resolution of the data for the most part is anywhere between 4 seconds to a minute.

The ASPM airport data provides detailed information on airport operations, capacity and weather every quarter hour. It also provides average wind speed and direction information, used in this analysis to estimate aircraft's true airspeed. 
BADA is an Aircraft Performance Model (APM) developed and maintained by EUROCONTROL through active cooperation with aircraft manufacturers and operating airlines. This analysis uses BADA operations performance parameters for individual aircraft type as an estimate for initial mass, surface area, drag and fuel burn coefficients etc. The equations for thrust, drag, and fuel burn are adopted from the BADA user manual version 3.8.

\section{B. Fuel Burn Model}

A review of existing literature on fuel burn estimation indicate that, using the standard International Civil Aviation Organization (ICAO) fuel burn rate and time in mode can result in overestimation of total fuel burn? Instead, the fuel burn can be estimated with $5.4 \%$ of the actual value using a model based on suitable track position report ${ }^{8}$.

Aircrafts burn fuel at a higher rate in the terminal area due to level offs and change of aircraft configuration from clean to dirty. This fuel burn model captures these two aspects of terminal arrival flows by taking into consideration the energy state (kinetic - true air speed and potential - altitude) of the aircraft at each position report of the flight trajectory. The various modules of the fuel burn model is shown in Figure 5. The flight track analyzer module combines and processes the data from ASPM, BADA and NOP, and inputs it into the fuel burn model. For a given flight, the NOP provides the 4D trajectory and aircraft type. The flight track analyzer uses the 4D information and the wind information to estimate the velocity, acceleration, aircraft configuration at each time step. The aircraft type and the configuration is used to draw aircraft specific information (mass, wing reference area, drag and fuel burn coefficients) from the BADA. The details of the fuel burn, true airspeed, thrust and drag computation are discussed in the following sub sections.

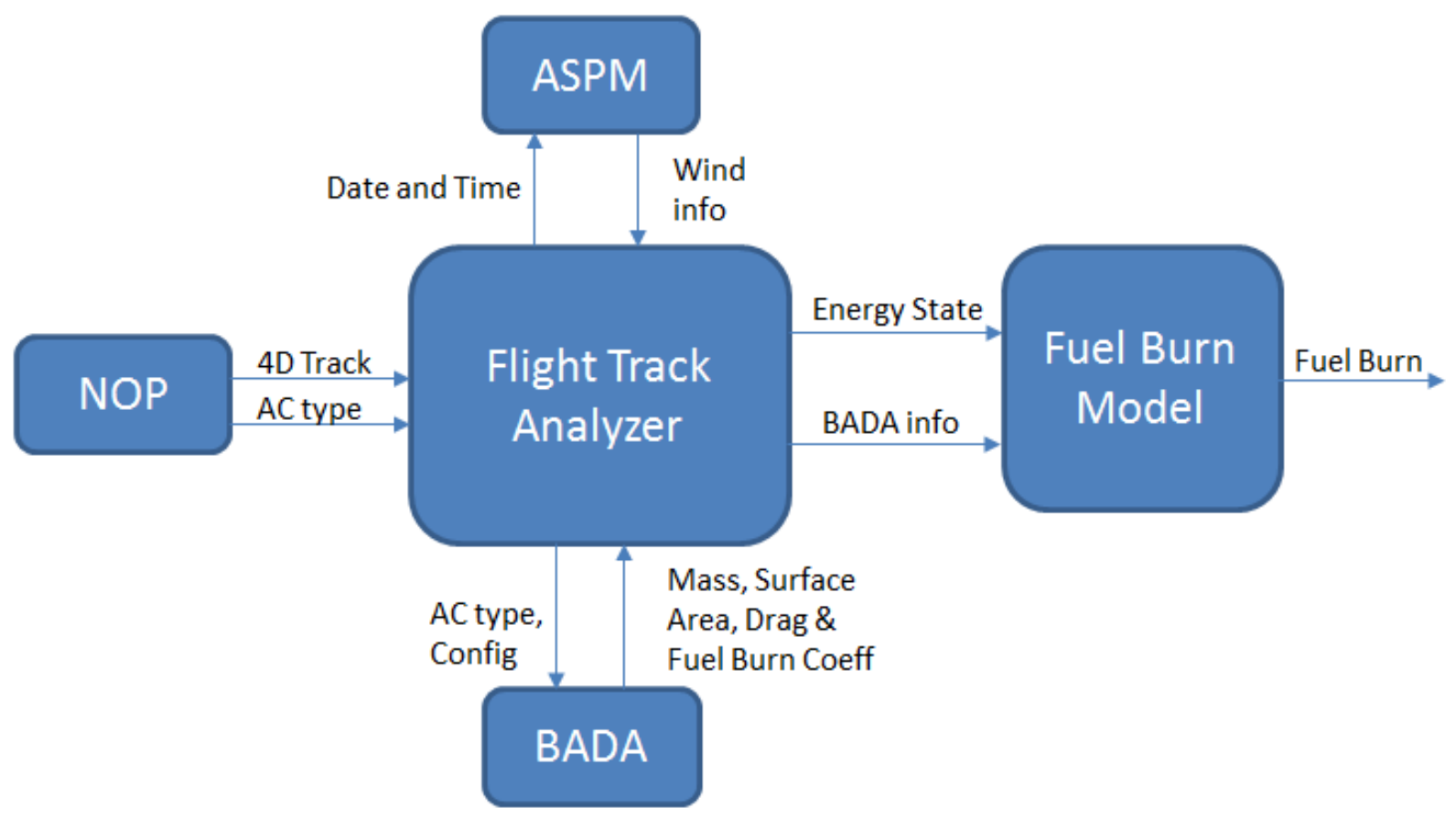

Figure 5. Fuel Burn Model

\section{Thrust Specific Fuel Burn}

The model computes total fuel burn for a 4D trajectory by summing up the fuel burn at each position report or time step $i$ (see Eq. 1). The fuel burn at each time step is computed as a product of the thrust and thrust specific fuel consumption (see Eq. 2). The expression for thrust specific fuel consumption is shown in Eq. 3. The thrust is estimated using the Total-Energy model, which equates the rate of work done by forces acting on the aircraft, to the rate of change of potential and kinetic energy (see Eq. 4). By rearranging the total energy model, the equation of thrust is obtained (see Eq. 5).

$$
F=\sum_{i} f_{i} \times\left(t_{i}-t_{i-1}\right)
$$




$$
\begin{gathered}
f_{i}=\eta_{i, \text { engine }} \times T_{i} \\
\eta_{i, j e t}=C_{f 1} \times\left(1+\frac{T A S_{i}}{C_{f 2}}\right), \eta_{i, \text { turboprop }}=C_{f 1} \times\left(1-\frac{T A S_{i}}{C_{f 2}}\right) \times\left(\frac{T A S_{i} \times 1.94}{1000}\right) \\
\left(T_{i}-D_{i}\right) \times T A S_{i}=m_{i} \times g \times \frac{d h}{d t}+m_{i} \times T A S_{i} \times \frac{d T A S}{d t} \\
T_{i}=D_{i}+\frac{m_{i} \times g \times \frac{d h}{d t}}{T A S_{i}}+m_{i} \times \frac{d T A S}{d t}
\end{gathered}
$$

Where,

$F$ is the total fuel burn for a $4 \mathrm{D}$ trajectory in $\mathrm{kg}$.

$f_{i}$ is the fuel burn rate in $\mathrm{kg} / \mathrm{min}$.

$t_{i}, t_{i-1}$ are the timestamps for positions $i$ and $i-1$.

$\eta_{i, \text { engine }}$ is the thrust specific fuel consumption in $\mathrm{kg} /(\mathrm{min} * \mathrm{kN})$.

$T_{i}$ is the thrust in $\mathrm{kN}$.

$D_{i}$ is the drag in $\mathrm{kN}$.

$C_{f 1}$ is the first thrust specific fuel consumption coefficients for an aircraft type in $\mathrm{kg} /(\mathrm{min} * \mathrm{kN})$ for jets and $\mathrm{kg} /(\min * \mathrm{knots} * \mathrm{kN})$ for turbo jets

$C_{f 2}$ is the second thrust specific fuel consumption coefficient for an aircraft type in $\mathrm{m} / \mathrm{s}$.

$T A S_{i}$ is the true airspeed of the aircraft in $\mathrm{m} / \mathrm{s}$.

$d h$ is the change in altitude $=h_{i}-h_{i-1}$ in $\mathrm{m}$

$d T A S$ is the change in true airspeed $=T A S_{i}-T A S_{i-1}$ in $\mathrm{m} / \mathrm{s}$

$d t$ is the time step increment $=t_{i}-t_{i-1}$ in $\mathrm{s}$

$m_{i}$ is the mass of the aircraft in $\mathrm{kg}$.

$g$ is acceleration due to gravity $=9.81 \mathrm{~m} / \mathrm{s}^{2}$.

The mass of the aircraft is initially assumed to be the mean of the operating empty weight and the maximum landing weight. For subsequent time steps the mass of the fuel burnt at each step is subtracted from the mass of the aircraft. The true airspeed, aircraft configuration and drag are computed at each time step. These are discussed in the following sections.

\section{True Airspeed}

The time step between position reports in the NOP data for the most part vary from four seconds to a minute. In this analysis the 4D trajectories are consolidated such that the time steps are at least thirty seconds. This is done to reduce noise in the velocity profile. In addition a differential equation forward filter is used to further smoothen the velocity profile 9 . The true airspeed is computed at each time step based on the ground speed and the wind speed. The true airspeed is given by,

$$
T A S_{i}=\left|\left(\begin{array}{c}
G S_{i} \times \sin \theta_{i} \\
G S_{i} \times \cos \theta_{i}
\end{array}\right)-\left(\begin{array}{c}
W S_{i} \times \sin \phi_{i} \\
W S_{i} \times \cos \phi_{i}
\end{array}\right)\right|
$$

Where,

$G S_{i}$ is the ground speed in $\mathrm{m} / \mathrm{s}$

$\theta_{i}$ is the aircraft bearing with respect to the north in radian.

$W S_{i}$ is the wind speed in $\mathrm{m} / \mathrm{s}$

$\phi_{i}$ is the wind bearing with respect to the north in radian

The ground speed and the aircraft bearing are computed using the following equations:

$$
\begin{gathered}
G S_{i}=\frac{R \times c_{i}}{t_{i}-t_{i-1}} \\
\left.c_{i}=2 \times \operatorname{atan} 2(\sqrt{b}, \sqrt{(1}-b)\right)
\end{gathered}
$$




$$
\begin{array}{r}
b=\sin ^{2}\left(\frac{\varphi_{i}-\varphi_{i-1}}{2}\right)+\cos \left(\varphi_{i-1}\right) \cos \left(\varphi_{i}\right) \sin ^{2}\left(\frac{\lambda_{i}-\lambda_{i-1}}{2}\right) \\
\theta_{i}=\operatorname{atan} 2\left(\sin \left(\lambda_{i}-\lambda_{i-1}\right) \cos \left(\varphi_{i}\right), \cos \left(\varphi_{i-1}\right) \sin \left(\varphi_{i}\right)\right. \\
\left.-\sin \left(\varphi_{i-1}\right) \cos \left(\varphi_{i}\right) \cos \left(\lambda_{i}-\lambda_{i-1}\right)\right)
\end{array}
$$

Where,

$\mathrm{R}$ is the radius of the earth $=6378100 \mathrm{~m}$.

$c_{i}$ is the haversine central angle between two coordinates $\left(\varphi_{i-1}, \lambda_{i-1}\right)$ and $\left(\varphi_{i}, \lambda_{i}\right)$

$\varphi_{i}, \varphi_{i-1}$ are the latitude for positions $i$ and $i-1$

$\lambda_{i}, \lambda_{i-1}$ are the longitude for positions $i$ and $i-1$

$t, t_{i-1}$ are the timestamps for position $i$ and $i-1 \mathrm{~s}$

The wind speed and wind bearing reported in the ASPM data is measured at ten meters from the surface. The wind speeds increase with altitude and is estimated using the power law wind profile equation ${ }^{3}$.

$$
W S_{i}=z_{g}\left(\frac{h_{i}}{h_{g}}\right)^{\alpha}
$$

Where,

$z_{g}$ is the velocity of the wind at height $h_{g}=10 \mathrm{~m}$, in $\mathrm{m} / \mathrm{s}$.

$h_{i}$ is the height of the aircraft above ground in $\mathrm{m}$.

$\alpha$ is the Hellman exponent $=0.3$ for human inhabited areas.

\section{Drag Computation}

The drag force on the aircraft is computed using the following equations

$$
\begin{gathered}
D_{i}=\frac{C_{D} \times \rho_{i} \times T A S_{i}^{2} \times S}{2} \\
\rho_{i}=\frac{p_{i} \times M}{R \times T} \\
p_{i}=p_{0}\left(1-\frac{L \times h_{i}^{\prime}}{T_{0}}\right) \\
T=T_{0}-L \times h_{i}^{\prime}
\end{gathered}
$$

Where,

$C_{D}$ is the coefficient of drag

$\rho_{i}$ is the density of the aircraft in $\mathrm{kg} / \mathrm{m}^{3}$.

$h_{i}^{\prime}$ is the altitude of the aircraft above sea level in $\mathrm{m}$.

$S$ is the wing reference area in $\mathrm{m}^{2}$.

$p_{0}$ is the sea level atmospheric pressure $=101.325 \mathrm{kPa}$

$p_{i}$ is the pressure at altitude $h_{i}^{\prime}$ in $\mathrm{kPa}$

$L$ is the temperature lapse rate $=0.0065 \mathrm{~K} / \mathrm{m}$

$T_{0}$ is the sea level standard temperature $=288.15 \mathrm{~K}$

$M$ is the molar mass of dry air $=0.0289644 \mathrm{~kg} / \mathrm{mol}$

$R$ is the universal gas constant $=8.31477 \mathrm{~J} /($ mol.K $)$

$T$ is the absolute temperate in $\mathrm{K}$.

American Institute of Aeronautics and Astronautics 
Table 1. Criteria for Aircraft Configuration

\begin{tabular}{|c|c|c|}
\hline Altitude & Velocity Threshold & Config \\
\hline$>1700 \mathrm{ft} \&<=8000$ & TAS $>=$ VminCruise & Clean \\
\hline$>1700 \mathrm{ft} \&<=8000$ & VminApproach $<=$ TAS $<$ VminCruise & Approach \\
\hline$<=1700 \mathrm{ft}$ & None & Landing \\
\hline
\end{tabular}

The coefficient of drag in Eq.12, is a function of the coefficient of lift and the configuration of the aircraft. For terminal arrival flows, an aircraft is assumed to be in clean, approach or landing configuration at each time step based on the true airspeed and the altitude of the aircraft. At MDW the criteria for selecting the configuration of the aircraft is shown in Table 1. In this analysis all flight trajectories are below 8000 feet. The minimum velocity (Vmin) for each configuration is 1.3 times the stall speed.

The coefficient of drag for clean, approach and landing configuration is given by Eq 16, Eq 17 and Eq 18. The coefficient of lift is given by Eq 19.

$$
\begin{gathered}
C_{D}=C_{D 0, C R}+C_{D 2, C R} \times C_{L}^{2} \\
C_{D}=C_{D 0, A P}+C_{D 2, A P} \times C_{L}^{2} \\
C_{D}=C_{D 0, L D}+C_{D 0, L D G}+C_{D 2, L D} \times C_{L}^{2} \\
C_{L}=\frac{2 \times m \times g}{\rho_{i} \times T A S_{i}^{2} \times S \times \cos \psi}
\end{gathered}
$$

Where,

$C_{L}$ is the coefficient of lift.

$C_{D 0, C R} C_{D 0, A P} C_{D 0, L D}$ are the parasitic drag coefficient for cruise, approach and landing configuration.

$C_{D 2, C R} C_{D 2, A P} C_{D 2, L D}$ are the induced drag coefficient for cruise, approach and landing configuration.

$C_{D 0, L D G}$ is the parasitic drag coefficient of the landing gear.

$\psi$ is bank angle, assumed to be zero in this analysis.

\section{Results}

The results section is organized as follows, the first subsection gives a summary of number of track processed and the aircraft types at MDW, the second, third and fourth subsections describe the fuel burn performance of arrivals at MDW. The fuel burn is computed for runways $13 \mathrm{C}, 31 \mathrm{C}, 22 \mathrm{~L}$ and $4 \mathrm{R}$, by individual flows, by approach type and on the whole irrespective of flows or approach type. The runways are ranked (from least to most) based on the fuel burn statistics. The final subsection discusses the relationship between level offs and fuel burn for terminal area flows.

\section{A. Summary of data processed}

The analysis is conducted using National Offload Program (NOP) data for 43 days selected to provide data for the 16 flows at MDW. After filtering out general aviation flight a total 11,275 tracks were processed. A total of 438 tracks were filtered out as noise or go-arounds.

At MDW there are 98 aircraft types (jets and turbo props). The list of aircraft types in each category is shown in Figure 6 . The narrow body aircrafts account of $76 \%$ of the flights, followed by business jets (15\%), regional jets (5\%) and turbo props (4\%). The most dominant aircraft type the Boeing 73 's, accounts for $72 \%$ of the flights at MDW. 


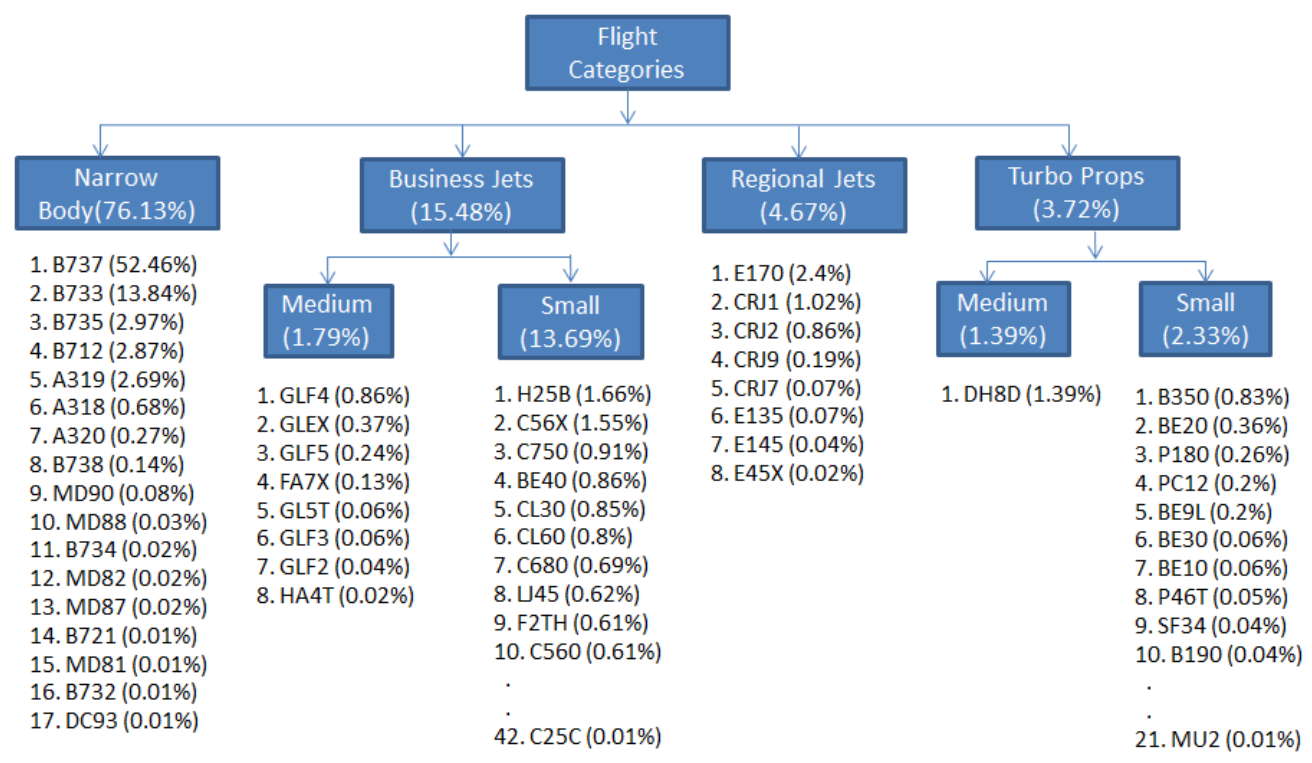

Figure 6. Aircraft types under each category at MDW

\section{B. Fuel Burn Performance Statistics by flow.}

At MDW all arrival flows except for the RNP approach on to $13 \mathrm{C}$ have a fleet mix shown in Figure 6. The RNP approach on to 13C first published in 2011, is flown mostly by Boeing 737's (B73's) on a limited basis. This section discusses fuel burn performance statistics for flows from the east and west for all aircrafts types, these are shown in Table 2 and Table 3. Also, to show the benefits of RNP approach, the fuel burn performance of Boeing 737's are also computed, shown in Table 4 and Table 5. The tables also show track time, level time statistics and the mean level time to track time ratio. The track time is the total time taken by the flight from the final waypoint on the STAR to the runway threshold. The level time is the total level off time from the final waypoint on the STAR to the runway threshold, i.e. when the change is the vertical profile is less than 100 feet per minute. The flows are ranked (from least to most) based on the average fuel burn per flight.

From the east ILS and Visual approaches on to runway $31 \mathrm{C}(100.48 \mathrm{~kg}$ and $100.72 \mathrm{~kg}$ ) have the lowest average fuel burn per flight followed by, visual approaches on to runways $22 \mathrm{~L}, 4 \mathrm{R}$ and $13 \mathrm{C}(140.20 \mathrm{~kg}, 189.14 \mathrm{~kg}$ and $206.28 \mathrm{~kg})$, ILS approach on to runway $4 \mathrm{R}(279 \mathrm{~kg})$ and runway $13 \mathrm{C}(336.5 \mathrm{~kg})$.

From the west ILS and visual approaches on to runway 4R (160.66 kg and $162.12 \mathrm{~kg})$ have the lowest fuel burn per flight followed by, Visual and ILS approaches on to runway $13 \mathrm{C}(181.19 \mathrm{~kg}$ and $215.68 \mathrm{~kg})$, Visual approaches on to runway $31 \mathrm{C}$ and $22 \mathrm{~L}(249.9 \mathrm{~kg}$ and $275.32 \mathrm{~kg})$ and ILS approach on to runway $31 \mathrm{C}(313.4 \mathrm{~kg})$.

When tower managers must pick a runway configuration in no wind condition, $13 \mathrm{C}$ is the most equitable runway with the 14\% difference in fuel burn for VFR flights from the east and the west, followed by, 4R (18\%), 22L (96\%) and $31 \mathrm{C}(148 \%)$. The same is true during IMC, $13 \mathrm{C}(56 \%)$ is the most equitable runway followed by $4 \mathrm{R}(72 \%)$ and $31 \mathrm{C}(211 \%)$.

Operational efficiency is maximized when the arrival flow crosses the final waypoint on the STAR and flies a straight course onto the runway. The ILS and Visual approaches from the east on to runway $31 \mathrm{C}$ and from the west on to $4 \mathrm{R}$, have a straight approach from the final way point on the STAR. The fuel burn performance of these flows are the best, when compared to other flows from the same direction 
Table 2. Fuel burn, Track time and Level time Statistics for flows from the east, for all aircrafts

\begin{tabular}{|c|c|c|c|c|c|c|c|c|c|c|}
\hline \multirow{2}{*}{\multicolumn{3}{|c|}{\begin{tabular}{|c|} 
Flow \\
Dir/Rwy/Procedure \\
\end{tabular}}} & \multirow{3}{*}{$\begin{array}{r}\begin{array}{c}\text { Track } \\
\text { Count }\end{array} \\
345 \\
\end{array}$} & \multicolumn{2}{|c|}{$\begin{array}{l}\text { Fuel Burn } \\
\text { (kg/flight) }\end{array}$} & \multicolumn{2}{|c|}{$\begin{array}{c}\text { Track time } \\
\text { (min) }\end{array}$} & \multicolumn{2}{|c|}{$\begin{array}{l}\text { Level Time } \\
\text { (min) }\end{array}$} & \multirow{3}{*}{$\begin{array}{c}\begin{array}{c}\% \\
\text { Level }\end{array} \\
6.90\end{array}$} \\
\hline & & & & \multirow{2}{*}{$\begin{array}{c}\text { Mean } \\
100.48\end{array}$} & \multirow{2}{*}{$\begin{array}{c}\text { SD } \\
47.00\end{array}$} & \multirow{2}{*}{$\begin{array}{r}\text { Mean } \\
6.12 \\
\end{array}$} & \multirow{2}{*}{$\begin{array}{c}\text { SD } \\
0.80\end{array}$} & \multirow{2}{*}{$\begin{array}{r}\text { Mean } \\
0.42 \\
\end{array}$} & \multirow{2}{*}{$\begin{array}{c}\text { SD } \\
0.86\end{array}$} & \\
\hline $\mathrm{E}$ & $31 C$ & Visual & & & & & & & & \\
\hline$E$ & $31 C$ & ILS & 1467 & 100.72 & 45.77 & 5.90 & 0.69 & 0.43 & 0.74 & 7.26 \\
\hline$E$ & $22 \mathrm{~L}$ & Visual & 840 & 140.20 & 59.21 & 6.71 & 0.83 & 0.42 & 0.65 & 6.20 \\
\hline$E$ & $4 \mathrm{R}$ & Visual & 1181 & 189.14 & 101.82 & 8.84 & 1.77 & 2.25 & 1.74 & 25.51 \\
\hline $\mathrm{E}$ & $13 C$ & Visual & 1026 & 206.28 & 100.74 & 9.62 & 1.59 & 1.89 & 1.29 & 19.66 \\
\hline $\mathrm{E}$ & $4 R$ & ILS & 390 & 279.00 & 161.18 & 10.92 & 2.58 & 3.50 & 2.42 & 32.02 \\
\hline$E$ & $13 C$ & ILS & 798 & 336.50 & 164.49 & 14.37 & 2.21 & 6.40 & 2.50 & 44.53 \\
\hline
\end{tabular}

Table 3. Fuel burn, Track time and Level time Statistics for flows from the west, for all aircrafts

\begin{tabular}{|c|c|c|c|c|c|c|c|c|c|c|}
\hline \multirow{2}{*}{\multicolumn{3}{|c|}{$\begin{array}{c}\text { Flow } \\
\text { Dir/Rwy/Procedure }\end{array}$}} & \multirow{3}{*}{$\begin{array}{r}\text { Track } \\
\text { Count } \\
564 \\
\end{array}$} & \multicolumn{2}{|c|}{$\begin{array}{l}\text { Fuel Burn } \\
\text { (kg/flight) }\end{array}$} & \multicolumn{2}{|c|}{$\begin{array}{l}\text { Track time } \\
\text { (min) }\end{array}$} & \multicolumn{2}{|c|}{$\begin{array}{l}\text { Level Time } \\
\text { (min) }\end{array}$} & \multirow{2}{*}{$\begin{array}{c}\% \\
\text { Level }\end{array}$} \\
\hline & & & & Mean & SD & Mean & SD & Mean & SD & \\
\hline W & $4 \mathrm{R}$ & Visual & & 160.66 & 62.52 & 9.07 & 1.35 & 1.41 & 1.58 & 15.55 \\
\hline W & $4 R$ & ILS & 729 & 162.12 & 54.50 & 8.57 & 0.92 & 1.26 & 1.12 & 14.72 \\
\hline W & $13 C$ & Visual & 861 & 181.19 & 75.03 & 9.63 & 1.11 & 1.10 & 1.14 & 11.42 \\
\hline W & $13 C$ & ILS & 568 & 215.68 & 86.33 & 10.61 & 1.03 & 2.51 & 1.64 & 23.71 \\
\hline W & $31 C$ & Visual & 987 & 249.90 & 113.66 & 11.89 & 1.97 & 3.45 & 2.02 & 29.00 \\
\hline W & $22 \mathrm{~L}$ & Visual & 650 & 275.32 & 109.19 & 12.37 & 2.11 & 3.24 & 1.95 & 26.16 \\
\hline W & $31 C$ & ILS & 387 & 313.40 & 142.85 & 13.75 & 2.42 & 4.68 & 2.47 & 34.03 \\
\hline
\end{tabular}

Table 4 and Table 5 shows, how RNP approach compare to other flows. The RNP approach on to runway 13C ranks, second last among flows from the east and third among flows from the west. It also burns on an average 41$52 \mathrm{~kg}$ less fuel per flight per approach compared to the corresponding ILS approach and 0-114 $\mathrm{kg}$ more fuel per flight per approach compared to the corresponding visual approach. 
Table 4. Fuel burn, Track time and Level time Statistics for flows from the east, For B73's

\begin{tabular}{|c|c|c|c|c|c|c|c|c|c|c|}
\hline \multirow{2}{*}{\multicolumn{3}{|c|}{$\begin{array}{c}\text { Flow } \\
\text { Dir/Rwy/Procedure }\end{array}$}} & \multirow{3}{*}{$\begin{array}{r}\text { Track } \\
\text { Count } \\
961 \\
\end{array}$} & \multicolumn{2}{|c|}{$\begin{array}{l}\text { Fuel Burn } \\
\text { (kg/flight) }\end{array}$} & \multicolumn{2}{|c|}{$\begin{array}{l}\text { Track time } \\
\text { (min) }\end{array}$} & \multicolumn{2}{|c|}{$\begin{array}{l}\text { Level Time } \\
\text { ( } \mathrm{min})\end{array}$} & \multirow{3}{*}{$\begin{array}{r}\begin{array}{c}\% \\
\text { Level }\end{array} \\
6.91 \\
\end{array}$} \\
\hline & & & & \multirow{2}{*}{$\begin{array}{c}\text { Mean } \\
119.49 \\
\end{array}$} & \multirow{2}{*}{$\begin{array}{c}\text { SD } \\
39.59\end{array}$} & \multirow{2}{*}{$\begin{array}{r}\text { Mean } \\
5.92 \\
\end{array}$} & \multirow{2}{*}{$\begin{array}{l}\text { SD } \\
0.72\end{array}$} & \multirow{2}{*}{$\begin{array}{r}\text { Mean } \\
0.41 \\
\end{array}$} & \multirow{2}{*}{$\begin{array}{l}\text { SD } \\
0.77\end{array}$} & \\
\hline$E$ & $31 C$ & ILS & & & & & & & & \\
\hline$E$ & $31 \mathrm{C}$ & Visual & 215 & 121.03 & 39.68 & 6.14 & 0.91 & 0.43 & 0.93 & 7.03 \\
\hline$E$ & $22 \mathrm{~L}$ & Visual & 606 & 158.09 & 48.35 & 6.69 & 0.80 & 0.39 & 0.64 & 5.76 \\
\hline$E$ & $4 R$ & Visual & 842 & 216.36 & 95.36 & 8.72 & 1.81 & 2.11 & 1.72 & 24.16 \\
\hline$E$ & $13 C$ & Visual & 673 & 248.06 & 78.27 & 9.59 & 1.60 & 1.84 & 1.31 & 19.22 \\
\hline$E$ & $4 R$ & ILS & 285 & 328.15 & 149.86 & 10.94 & 2.61 & 3.52 & 2.40 & 32.20 \\
\hline $\mathbf{E}$ & $13 C$ & RNP & 87 & 362.26 & 91.46 & 13.32 & 2.08 & 4.69 & 1.96 & 35.21 \\
\hline$E$ & $13 C$ & ILS & 520 & 414.67 & 121.84 & 14.30 & 2.14 & 6.38 & 2.49 & 44.62 \\
\hline
\end{tabular}

Table 5. Fuel burn, Track time and Level time Statistics for flows from the west, for B73's

\begin{tabular}{|c|c|c|c|c|c|c|c|c|c|c|}
\hline \multirow{2}{*}{\multicolumn{3}{|c|}{$\begin{array}{c}\text { Flow } \\
\text { Dir/Rwy/Procedure }\end{array}$}} & \multirow{3}{*}{$\begin{array}{r}\begin{array}{l}\text { Track } \\
\text { Count }\end{array} \\
548 \\
\end{array}$} & \multicolumn{2}{|c|}{$\begin{array}{l}\text { Fuel Burn } \\
\text { (kg/flight) }\end{array}$} & \multicolumn{2}{|c|}{$\begin{array}{l}\text { Track time } \\
\text { (min) }\end{array}$} & \multicolumn{2}{|c|}{$\begin{array}{l}\text { Level Time } \\
\text { (min) }\end{array}$} & \multirow{3}{*}{$\begin{array}{c}\% \\
\text { Level } \\
14.49 \\
\end{array}$} \\
\hline & & & & \multirow{2}{*}{$\begin{array}{c}\text { Mean } \\
178.17 \\
\end{array}$} & \multirow{2}{*}{$\begin{array}{c}\text { SD } \\
42.04 \\
\end{array}$} & \multirow{2}{*}{$\begin{array}{r}\text { Mean } \\
8.51 \\
\end{array}$} & \multirow{2}{*}{$\begin{array}{c}\text { SD } \\
0.88 \\
\end{array}$} & \multirow{2}{*}{$\begin{array}{r}\text { Mean } \\
1.23 \\
\end{array}$} & \multirow{2}{*}{$\begin{array}{c}\text { SD } \\
1.06 \\
\end{array}$} & \\
\hline W & $4 R$ & ILS & & & & & & & & \\
\hline$W$ & $4 R$ & Visual & 423 & 178.40 & 54.16 & 8.95 & 1.17 & 1.22 & 1.40 & 13.68 \\
\hline$w$ & $13 C$ & RNP & 144 & 206.31 & 46.70 & 9.44 & 0.83 & 1.25 & 1.06 & 13.28 \\
\hline W & $13 C$ & Visual & 615 & 206.47 & 56.89 & 9.59 & 1.11 & 1.02 & 1.10 & 10.68 \\
\hline W & $13 C$ & ILS & 416 & 247.56 & 64.54 & 10.57 & 0.96 & 2.44 & 1.61 & 23.11 \\
\hline W & $31 C$ & Visual & 734 & 286.98 & 95.86 & 11.82 & 1.91 & 3.35 & 1.93 & 28.36 \\
\hline W & $22 \mathrm{~L}$ & Visual & 495 & 306.80 & 90.87 & 12.37 & 2.04 & 3.19 & 1.90 & 25.79 \\
\hline W & $31 C$ & ILS & 295 & 355.2 & 122.9 & 13.63 & 2.4 & 4.535 & 2.5 & 33.27 \\
\hline
\end{tabular}

\section{Fuel Burn Performance Statistics by approach type.}

In Table 6 (fleet mix) and Table 7 (only B737s) the flows from the east and west are consolidated (assuming equal weights for traffic from the east and the west) and are ranked by approach type, based on the average fuel burn per flight. Runway $22 \mathrm{~L}$ does on have an ILS approach and only runway $13 \mathrm{C}$ has a RNP approach (see Table 7).

For the fleet mix at MDW, the ranking of runways for ILS approach is $31 \mathrm{C}(207.06 \mathrm{~kg})$ followed by, $4 \mathrm{R}$ $(+6.5 \%)$ and $13 \mathrm{C}(+33 \%)$. For visual approach the ranking is $4 \mathrm{R}(174.9 \mathrm{~kg})$ followed by, $31 \mathrm{C}(+.1 \%), 13 \mathrm{C}(+11 \%)$, and 22L $(+19 \%)$.

The fuel burn for visual approaches on to runways $31 \mathrm{C}$, $4 \mathrm{R}$ and $13 \mathrm{C}$, in less than the corresponding ILS approach by $15 \%, 20 \%$ and $30 \%$ respectively. 
Table 6. Fuel burn, Track time, Level Time Statistics for all aircrafts at MDW, by approach type

\begin{tabular}{|c|c|c|c|c|c|c|c|c|c|}
\hline \multirow{2}{*}{\multicolumn{2}{|c|}{$\begin{array}{l}\text { Runway/ } \\
\text { Approach }\end{array}$}} & \multirow{3}{*}{$\begin{array}{r}\begin{array}{c}\text { Track } \\
\text { Count }\end{array} \\
1854 \\
\end{array}$} & \multicolumn{2}{|c|}{$\begin{array}{l}\text { Fuel Burn } \\
\text { (kg/flight) }\end{array}$} & \multicolumn{2}{|c|}{$\begin{array}{l}\text { Track time } \\
\text { (min) }\end{array}$} & \multicolumn{2}{|c|}{$\begin{array}{l}\text { Level Time } \\
\text { (min) }\end{array}$} & \multirow{3}{*}{$\begin{array}{c}\begin{array}{c}\% \\
\text { Level }\end{array} \\
25.99 \\
\end{array}$} \\
\hline & & & \multirow{2}{*}{$\begin{array}{l}\text { Mean } \\
207.06 \\
\end{array}$} & \multirow{2}{*}{$\begin{array}{c}\text { SD } \\
150.20\end{array}$} & \multirow{2}{*}{$\begin{array}{r}\text { Mean } \\
9.83 \\
\end{array}$} & \multirow{2}{*}{$\begin{array}{c}\text { SD } \\
4.31 \\
\end{array}$} & \multirow{2}{*}{$\begin{array}{r}\text { Mean } \\
2.55 \\
\end{array}$} & \multirow{2}{*}{$\begin{array}{c}\text { SD } \\
2.80\end{array}$} & \\
\hline $31 C$ & ILS & & & & & & & & \\
\hline $4 \mathrm{R}$ & ILS & 1119 & 220.56 & 133.75 & 9.75 & 2.27 & 2.38 & 2.19 & 24.41 \\
\hline $13 C$ & ILS & 1366 & 276.09 & 144.58 & 12.49 & 2.55 & 4.46 & 2.87 & 35.69 \\
\hline $4 R$ & Visual & 1745 & 174.90 & 85.68 & 8.95 & 1.58 & 1.83 & 1.71 & 20.46 \\
\hline $31 C$ & Visual & 1332 & 175.19 & 114.65 & 9.01 & 3.25 & 1.94 & 2.17 & 21.49 \\
\hline $13 C$ & Visual & 1887 & 193.74 & 89.70 & 9.62 & 1.37 & 1.50 & 1.28 & 15.54 \\
\hline $22 \mathrm{~L}$ & Visual & 1490 & 207.76 & 110.81 & 9.54 & 3.25 & 1.83 & 2.03 & 19.14 \\
\hline
\end{tabular}

For B737s, the RNP approach on to 13C requires an average of $14 \%$ less fuel than the ILS approach on to 13C. At $\$ 3 /$ gallon, this is equivalent to on an average a savings of $\$ 47$ per flight per approach. Also, the visual approach on to $13 \mathrm{C}$ burns on an average $20 \%$ per less fuel than the corresponding RNP approach.

Table 7. Fuel burn, Track time, Level Time Statistics for B73's at MDW, by approach type

\begin{tabular}{|c|c|c|c|c|c|c|c|c|c|}
\hline \multirow{2}{*}{\multicolumn{2}{|c|}{$\begin{array}{l}\text { Runway/ } \\
\text { Approach }\end{array}$}} & \multirow{3}{*}{$\begin{array}{r}\text { Track } \\
\text { Count } \\
1256 \\
\end{array}$} & \multicolumn{2}{|c|}{$\begin{array}{l}\text { Fuel Burn } \\
\text { (kg/flight) }\end{array}$} & \multicolumn{2}{|c|}{$\begin{array}{l}\text { Track time } \\
\text { (min) }\end{array}$} & \multicolumn{2}{|c|}{$\begin{array}{l}\text { Level Time } \\
\text { (min) }\end{array}$} & \multirow{3}{*}{$\begin{array}{c}\begin{array}{c}\% \\
\text { Level }\end{array} \\
25.29 \\
\end{array}$} \\
\hline & & & \multirow{2}{*}{$\begin{array}{l}\text { Mean } \\
237.36 \\
\end{array}$} & \multirow{2}{*}{$\begin{array}{c}\text { SD } \\
149.08\end{array}$} & \multirow{2}{*}{$\begin{array}{r}\text { Mean } \\
9.78 \\
\end{array}$} & \multirow{2}{*}{$\begin{array}{l}\text { SD } \\
4.24\end{array}$} & \multirow{2}{*}{$\begin{array}{r}\text { Mean } \\
2.47 \\
\end{array}$} & \multirow{2}{*}{$\begin{array}{c}\text { SD } \\
2.76 \\
\end{array}$} & \\
\hline $31 C$ & ILS & & & & & & & & \\
\hline $4 \mathrm{R}$ & ILS & 833 & 253.16 & 133.18 & 9.72 & 2.30 & 2.38 & 2.18 & 24.45 \\
\hline $13 C$ & ILS & 936 & 331.12 & 128.40 & 12.44 & 2.50 & 4.41 & 2.88 & 35.48 \\
\hline $13 C$ & RNP & 231 & 284.28 & 106.55 & 11.38 & 2.50 & 2.97 & 2.33 & 26.12 \\
\hline $4 \mathrm{R}$ & Visual & 1265 & 197.38 & 79.84 & 8.83 & 1.53 & 1.67 & 1.63 & 18.85 \\
\hline $31 C$ & Visual & 949 & 204.00 & 110.76 & 8.98 & 3.21 & 1.89 & 2.10 & 21.07 \\
\hline $13 C$ & Visual & 1288 & 227.27 & 71.51 & 9.59 & 1.38 & 1.43 & 1.28 & 14.95 \\
\hline $22 \mathrm{~L}$ & Visual & 1101 & 232.4 & 104.1 & 9.529 & 3.2 & 1.787 & 2 & 18.76 \\
\hline
\end{tabular}

D. Fuel Burn Performance Statistics by runway.

In Table 8 overall ranking for runways is shown based on the fuel burn for total arrivals, irrespective of direction of flow or type of approach. In general the overall ranking of the runways is $31 \mathrm{C}, 4 \mathrm{R}(+3 \%), 22 \mathrm{~L}(+8.4 \%)$ and $13 \mathrm{C}$ $(+29 \%)$. 
Table 8. Fuel burn, Track time, Level Time Statistics for all aircrafts at MDW, by runway

\begin{tabular}{|c|c|c|c|c|c|c|c|c|}
\hline \multirow[b]{2}{*}{ Runway } & \multirow{2}{*}{$\begin{array}{l}\text { Track } \\
\text { Count }\end{array}$} & \multicolumn{2}{|c|}{$\begin{array}{l}\text { Fuel Burn } \\
\text { (kg/flight) }\end{array}$} & \multicolumn{2}{|c|}{$\begin{array}{l}\text { Track time } \\
\text { (min) }\end{array}$} & \multicolumn{2}{|c|}{ Level Time (min) } & \multirow{2}{*}{$\begin{array}{c}\% \\
\text { Level }\end{array}$} \\
\hline & & Mean & SD & Mean & SD & Mean & SD & \\
\hline $31 \mathrm{C}$ & 3186 & 191.12 & 134.56 & 9.42 & 3.84 & 2.24 & 2.52 & 23.84 \\
\hline $4 R$ & 2864 & 197.73 & 114.62 & 9.35 & 1.99 & 2.11 & 1.99 & 22.52 \\
\hline $22 \mathrm{~L}$ & 1490 & 207.76 & 110.81 & 9.54 & 3.25 & 1.83 & 2.03 & 19.14 \\
\hline $13 \mathrm{C}$ & 3487 & 250.94 & 123.27 & 11.16 & 2.51 & 2.98 & 2.56 & 26.69 \\
\hline
\end{tabular}

\section{E. Fuel burn Level Vs. Non Level}

For each trajectory the fuel burn model takes into account the energy state (i.e. kinetic - true air speed and potential - altitude) of the aircraft at each position report. The model estimates the fuel burn rate in level segments and non-level segments while taking into consideration the configuration of the aircraft (clean, or dirty). This is illustrated in Figure 7 , where two sample trajectories for a B737 on to runway $13 \mathrm{C}$ from the east are shown. The lateral and the vertical profile are shown in plot (a) and (b), and the true airspeed and fuel burn rate are shown in plot (c) and (d). The vertical profile, the true airspeed and the fuel burn rate are shown as a function of distance to the runway threshold.

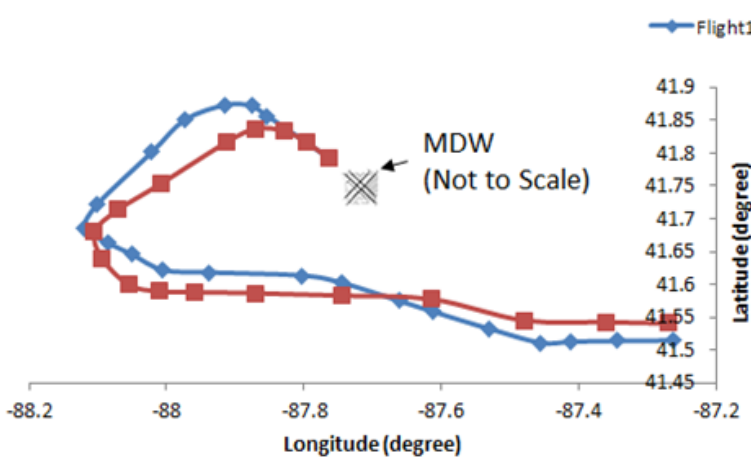

(a)

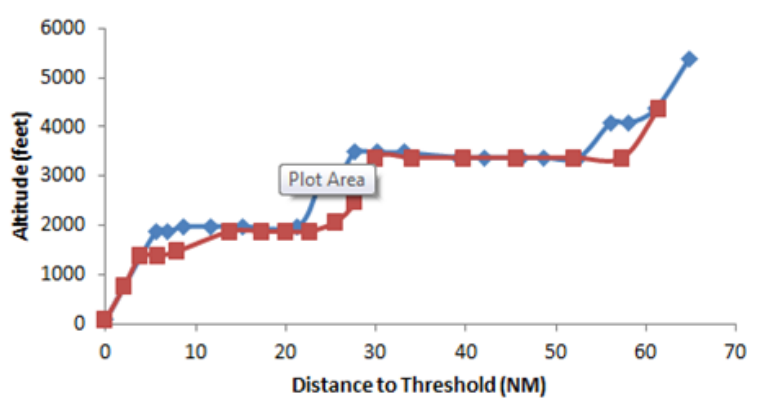

(b)

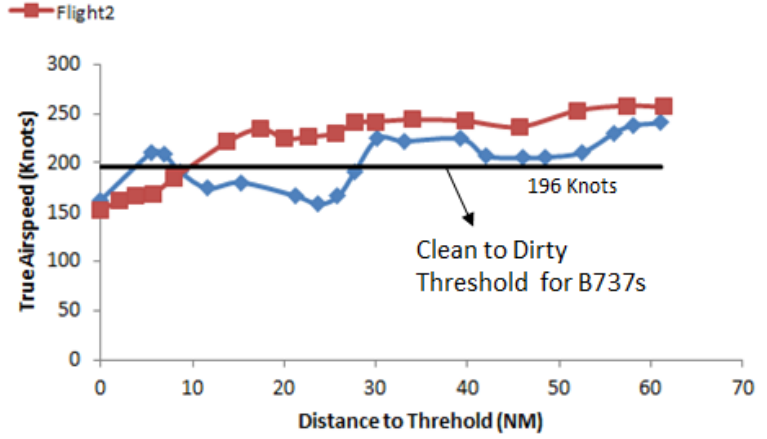

(c)

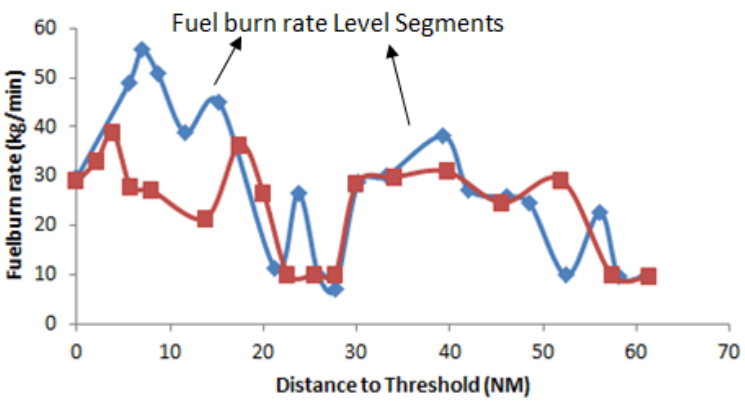

(d)

Figure 7. Sample Flight Trajectories onto runway $13 \mathrm{C}$ from the East

The model captures the higher fuel burn rate in the levels segments compared to the non-level segments.(see Figure 7, plot b and d). The model also captures increase in fuel burn as results of switch from clean to dirty configuration. For instance, the flight1 (blue) burn more fuel as it switches from clean to dirty sooner than flight2 (red), as shown in Figure 7 (c).

Figure 8, shows the mean and standard deviation of fuel burnt on level, descent and final approach for narrow body aircrafts at MDW. The fuel burn on the level segments is on an average $108 \%$ more than on the descent segments and $25 \%$ more than on the final approaches. 


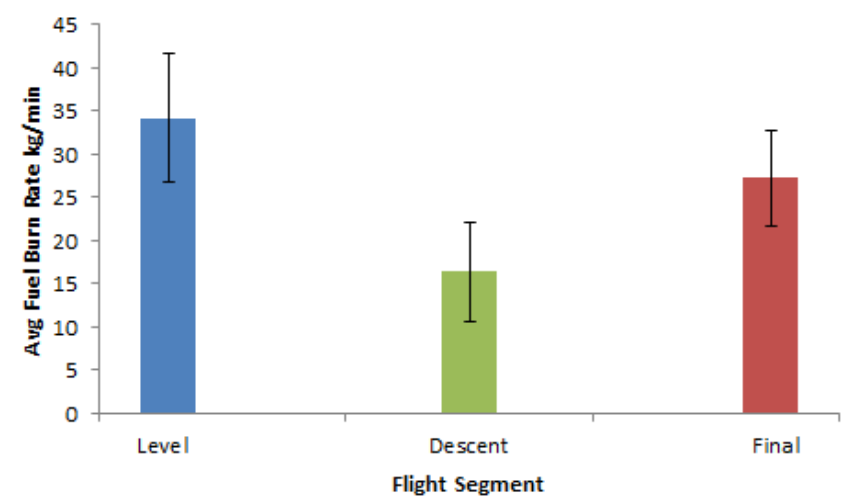

Figure 8. Average Fuel burn rate and Standard Deviation for Level, Descent and Final Approach Segments, for narrow body aircrafts

The fuel burn for individual TRACON flows is not proportional to the track time (see Figure 9 (b)). The main factor that contribute to higher fuel burn are the percentage level segments. The influence of level segments on total fuel burn is shown in Figure 9. In the terminal area, irrespective of the duration of the flow (see Figure 9 (a), shown in blue), the time spent in descending and final approach and the corresponding fuel burn is more or less constant, as shown by the green and red line. Any increase in the total transit time in the terminal area is due to increase in the level segments, shown by the purple line. Therefore, longer approaches have a higher percentage of level segments and a nonlinear increase in fuel burn.

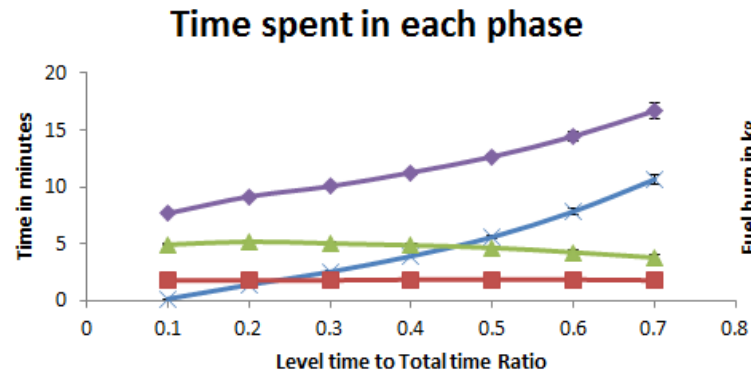

(a)

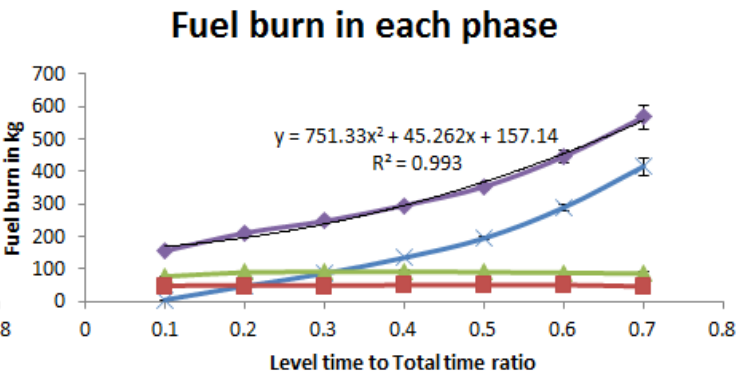

(b)

Figure 9. Influence of level segments on total fuel burn

\section{Conclusion}

This paper presents a methodology to estimate fuel burn using actual trajectory of the aircraft, while taking into consideration the energy state (kinetic - true air speed, potential - altitude) of the aircraft at each position report of the flight trajectory. The model captures the higher fuel burn rate in the levels segments compared to the non-level segments. The model also captures increase in fuel burn as results of switch from clean to dirty configuration.

The fuel burn is estimated for 16 major arrival flows at MDW using 43 days of NOP track data. The fuel burn performance statistics of flows are used to rank the runways at MDW. The fuel burn per flight in the terminal area is used to rank runways based on, the individual flows from east and west, the approach procedures irrespective of flow direction and the overall efficiency irrespective of approach type and flow direction.

\section{A. Role of Level Segments in Approach}


For narrow body aircrafts at MDW, the fuel burn rate in level flights ( $35 \mathrm{~kg} / \mathrm{min})$ is $108 \%$ greater than fuel burn for near-idle descent segments $(15 \mathrm{~kg} / \mathrm{min})$ and $25 \%$ greater than fuel burn on the final approach segment $(25$ $\mathrm{kg} / \mathrm{min})$.

\section{B. RNP Benefits}

The results of analysis show that during Instrument Meteorological Conditions (IMC), the RNP approach to 13C requires an average of $14 \%$ less fuel than the ILS approach on to $13 \mathrm{C}$. For narrow body aircrafts, this is equivalent to on an average a savings of $\$ 47$ per flight per approach (at \$3 a gallon).

\section{Optimum Runway Configurations}

During Visual Meteorological Conditions (VMC), assuming equal weights for arrivals from the east and west, the least average fuel burn arrival flow for VFR approach procedures is $4 \mathrm{R}(174.9 \mathrm{~kg})$ followed by, 31C (+.1\%), 13C (+11\%), and 22L (+19\%). During Instrument Meteorological Conditions (IMC), assuming equal weights for arrivals from the east and west, the least average fuel burn arrival flow for ILS approach procedures is $31 \mathrm{C}(207.06 \mathrm{~kg})$ followed by, $4 \mathrm{R}(+6.5 \%)$ and $13 \mathrm{C}(+33 \%)$. This information combined with the prevailing wind conditions can be used to select runway configurations that is optimal both in terms of wind and terminal fuel burn.

\section{Equitable Fuel-burn Runway Configurations}

$13 \mathrm{C}$ is the most equitable runway with the $14 \%$ difference in fuel burn for VFR flights from east and west followed, 4R (18\%), 22L (96\%) and 31C (148\%). The same is true during IMC, 13C (56\%) is the most equitable runway followed by $4 \mathrm{R}(72 \%)$ and $31 \mathrm{C}(211 \%)$.

The methodology described in the paper can be used determine the most and the least efficient flows in the terminal area for a given airport. These results indicate the benefits of the RNP approach and an opportunity for a decision-support tool to select runway configuration based on wind magnitude/direction, as well as fuel burn. The next step is to use the fuel burn statistic to estimate the benefits of RNP approach for an airline at an airport. At MDW, this includes creating hypothesized RNP approach procedures for other runways, determining optimal runway configuration based on wind and fuel burn, computing total savings per years in fuel burn as a result of, using RNP approaches and optimal runway configuration, and de-confliction of flows between MDW and Chicago O’Hare International airport (ORD).

\section{Acknowledgments}

This work is sponsored by Crown Consulting Inc. the FAA, NASA and by GMU internal research foundation funds. Acknowledgements for technical assistance to Mr. Michael Wambsganss, Anastasia Mukhina, Liviu Nedelscu, Matt Blake (Crown Consulting), Paula Lewis, Irina Ioachim, Jennifer Elewll, Joe Post, Almira Ramadani (FAA), Jim Fossey (Consultant).

\section{References}

${ }^{1}$ Belle, A., Sherry, L., Wambsganss, M., and Mukhina, A., "A Methodology for Airport Arrival Flow Analysis Using Track Data - A Case Study for MDW Arrivals," Integrated Communications Navigation and Surveillance Conference (ICNS), 2013.

${ }^{2}$ Base of Aircraft Data, "Base of Aircraft Data (BADA) v3.8 | EUROCONTROL" Available: http://www.eurocontrol.int/services/bada.

3 Panofsky, H. ., and Dutton, J. ., Atmospheric Turbulence, Wiley\&Sons, 1984.

${ }^{4}$ Oaks, R. ., and Ryan, H. ., "Prototype Implementation and Concept Validation of a 4-D Trajectory Fuel Burn Model Application," AIAA Guidance, Navigation and Control Conference, Toronto: 2010. 
${ }^{5}$ DeArmon, J., Mahashabde, A., Baden, W., and Kuzminski, P., "Applications of a Terminal Area Flight Path Library," 2011.

${ }^{6}$ ASPM System Overview, "ASPM System Overview - ASPMHelp" Available: http://aspmhelp.faa.gov/index.php/ASPM_System_Overview.

${ }^{7}$ Patterson, J., Noel, G. ., Senzig, D. ., Roof, C. ., and Fleming, G. ., "Analysis of Departure and Arrival Profiles Using Real-Time Aircraft Data," Journal of Aircraft, vol. 46, Aug. 2009, pp. 1095-1103.

${ }^{8}$ Chatterji, G. B., "Fuel Burn Estimation Using Real Track Data," 11 th AIAA ATIO Conference, 2011.

9 Jamet, D., "Smoothing Out GPS and Heat Rate Monitor Data," Aug. 2011. 